\title{
Whither Modern Byelorussian Lexis?
}

$\mathrm{BY}$

\author{
P.J. MAYO
}

The publication of A. Ja. Bachańkoǔ's survey, Raźvićcio leksiki bietaruskaj litaraturnaj movy $\check{u}$ saviecki pieryjad ('Navuka i technika', Minsk, 1982, 231 pp.), provides a suitable opportunity to consider the state of Byelorussian lexis in the Soviet period. This is a valuable, stimulating, at times irritating and ultimately rather depressing book: valuable because it is the first comprehensive survey of the development of Byelorussian lexis in the post-revolutionary era; stimulating because it contains much interesting information on the different stages and aspects of that development; irritating because, perhaps inevitably, too much is explained in political clichés rather than linguistic (including unpoliticized sociolinguistic) terms; ultimately depressing because the author, not entirely satisfied with the way that things have gone, concludes with a call for 'control' over the linguistic processes involved.

That language is not static but constantly evolving is a truism: nevertheless, it seems that even linguists need reminding from time to time that changes can rarely with success be either imposed or resisted from above. While a measure of prescription and normalization is possible, indeed desirable, where the grammatical structure of a language is concerned (though even then it should seek to reflect reality rather than attempt to impose its own concept of what that reality should be), we are faced with a much more difficult question when it comes to the lexicon which, more than any other aspect of language, is subject to rapid change and, especially in modern times, highly susceptible to external influences. Thus many émigré Byelorussians will no doubt be enraged by the abundant evidence to be found throughout Bachańkoú's book of the major role played by Russian in the development of the vocabulary of the modern Byelorussian literary language, both as a lexical source and as the principal medium for the introduction of loanwords from other languages. But this is to ignore not only political reality but the more fundamental linguistic reality of the close historical relationship between the two languages, a relationship which would be bound to have its effect irrespective of political considerations. One may lament the 'contamination' of one's language from outside - as people frequently do with regard to all sorts of languages - but it is simply not possible to turn the clock back and pretend that it has not happened. Linguistic purism has always been a dubious policy, whatever language it is applied to (witness the absurd lengths to which 
the French Academy is currently going in its attempts to cleanse French of foreign, especially English, contamination), and has often led to the creation of 'native' forms which, paradoxically, may seem more artificial than the loan-words they are coined to replace. In any case, in the context of Byelorussian, it is doubtful whether the average Soviet Byelorussian, even if he is aware of it, views the influence of Russian on his native language in such a negative light.

That said, it seems quite wrong to portray Russian, as Bachańkoŭ seeks to do, as a kind of inspiration or benefactor in the undoubted rapid expansion of Byelorussian's lexical resources in the 20th century. That Russia has been an agent of that expansion is undeniable, but it was an accident of history that the Revolution occurred at a time when the modern Byelorussian literary language was still in the relatively early stages of its development following the break with Old Byelorussian and its virtual suppression in the 18 th and 19 th centuries. Inevitably the establishment of a new order, and particularly one of the Soviet type, determined to some extent the way in which that process of development would continue, but the large increase in foreign lexis in particular in the Soviet period is due as much to the demands created by rapid technological and scientific advances and the ease of communication which have been such a prime feature of the 20th century, and it is in this light that one should approach Byelorussian lexicology. To be fair to Bachańkoŭ, he does give weight to these factors; it is just a pity that he usually feels the need to clothe them in political jargon.

Bachańkoǔ's book covers the period from the 1920s to the end of the 1970 s and is based on materials from various literary sources, but principally newspapers and journals, which the author sees as providing the 'freshest and richest' material (though, judging by his remarks at the end of the book, some of the material he encountered was just a little too fresh and rich for his taste). It is an attempt at synthesizing work that has been done on individual periods/lexical areas and at demonstrating the sources, paths of development and trends in the Byelorussian lexicon. The Introduction (pp.3-30) contains a brief survey of this work in which, for once, tribute is paid to such formerly unmentionable figures from the 1920s as Niekraševič. Bachańkoŭ has little to say about the period from the early 1930 s to the late 1950 s — not surprisingly, given the paucity of lexicological and lexicographical work in Byelorussian during the Stalin period. In referring back to the prerevolutionary state of the Byelorussian literary language, the role of Naša niva and the Hramada is acknowledged, if belittled by comparison with the Revolution. The author is right, of course, to point to the underdeveloped state of Byelorussian as a literary language prior to the Revolution, but it is scarcely appropriate, even in a Soviet publication, to give quite so much credit to Lenin and the Communist Party for its subsequent flowering. Surveying the social and historical factors which have influenced the development of modern Byelorussian and its lexis in particular, Bachańkoŭ consistently plays down the role of 
Polish and stresses the importance of Russian-Byelorussian bilingualism. With some justification he is severe on the puristic tendencies of some scholars in the 1920 s, though once again he cannot resist criticizing from a political as much as linguistic point of view.

It is thus with a sense of (not wholly justified) relief that one turns to the main body of Bachankoŭ's survey which is divided into four parts. The first (pp.31-67) deals with the role of the dialects in enriching the literary language; the second (pp.68-114) is concerned with derivational neologisms in the Soviet period; a short third section (pp.11526) examines the revival of archaisms; the fourth, and largest, section (pp.127-218) is devoted to foreign lexis.

Unlike many literary languages modern Byelorussian has a substantial dialect base because of the break with the literary language of earlier times. This fact complicates our understanding of where the dividing line lies between the concepts of 'dialect language' and 'literary language', and the picture was further complicated during the 19th and early 20 th centuries by the absence of orthographical, lexico-grammatical and stylistic norms. For the Soviet period Bachańkoú identifies three phases in the relationship between 'dialect' and 'literary' lexis. In the first of these, the 1920s, the contrast between the two was very marked in the scientific sphere, but not in creative literature or the press. It was a period of intensive lexicographical activity and terminological development as a considerable number of dictionaries dealing with specialist scientific areas were published. At the same time, reflecting the importance of dialect lexis at this time, work was begun on a number of regional dictionaries though, as Bachańkoŭ somewhat coyly puts it, 'for various reasons' only two came to fruition: M. Kaśpiarovič's Viciebski krajovy stoǔnik (1927) and M. Šaternik's Krajovy stoǔnik Červieńščyny (1929); while a third, A. Krukoǔski's Stoǔnik Mazyrščyny, was completed, but not published, and the manuscript perished during the Second World War. The second phase, the 1930s and 1940s, was a period of reaction against native Byelorussian dialect lexis and a corresponding Russification in the sphere of lexis as in others; this period is quickly glossed over by Bachankoŭ as part of the struggle with 'bourgeois nationalism'. Serious scholarly interest in lexicology and lexicography only revived after Stalin's death, towards the end of the $1950 \mathrm{~s}$, and one of the earliest important publications to result from this renewed interest was the Dyjalektny attas bietaruskaj movy, published by the Institute of Linguistics of the Academy of Sciences of the BSSR in 1963. Since then there has been a steady flow of lexicographical publications, including dialect dictionaries and culminating in the now complete Ttumačalny stoǔnik bietaruskaj movy. The extent to which dialect lexis has influenced the literary language has varied. Its use in the development of terminological systems in the 1920 s was short-lived and by the end of the decade this role was increasingly being fulfilled by international or Russian words. The adoption of international terminology was understandable since it was part of a more or less universal process still at work today, but the 
preference for Russian words over native dialect ones is hard to justify on purely linguistic grounds, given that Byelorussian has an equally good Slavonic pedigree. Why, for example, should савет be preferable to рада or, in anatomy, мышца to цягліца?

Another important function of the native resources provided by dialect lexis is to enrich the stylistic and expressive capabilities of the literary language by extending the range of synonym series. In Byelorussian this was at its height in the 1920 s and 1930 s, but has since come to be regarded in a more negative light. Such a reaction to what Bachańkoú describes as the excessive and arbitrary use of 'localisms' has tended to impoverish the language's lexico-stylistic resources as many words previously regarded as acceptable have come to be treated as archaic and/or narrowly dialectal. How far this process has been the natural weeding-out which occurs as a literary language develops and how far it has been imposed in the name of kultura movy is difficult for a non-native speaker of Byelorussian to assess, but the way in which Bachańkoŭ writes about it certainly suggests a hand on the scales. He bemoans the fact that in some synonym pairs containing native Byelorussian and what he describes as 'common East Slavonic' members it is the former which have survived at the expense of those words which coincide - or very nearly coincide - with Russian words (е.g. вёска, бульба, люстэрка in preference to дзярэўня, картофрля, зеркала respectively). Such 'purism', of which Bachańkoǔ sees Niekraševič as an extreme exponent, is regretted by him and he appears delighted to discover that many words of 'common East Slavonic' (Russian?) origin which had previously been rejected (е.g. дзела, ждаць, заметны, прыбор) are included in the Ttumačalny stoúnik biełaruskaj movy as fully-fledged members of the literary language. Despite these vicissitudes, dialect lexis has been a fruitful source of neologisms in modern Byelorussian and is estimated, even by Bachańkoǔ, to account for around one-third of the total.

Among derivational neologisms in the Byelorussian language of the Soviet period it is calques and semi-calques which predominate. Native Byelorussian derivational neologisms of the type спадчынны, спадчыннык, спадчыннасць («спадчына); страўнік, сграваванне, стрававальны («страва): чыгуначны, чыгуначнік («чыгунка) are few in number. However paradoxically, it may seem less artificial to model new words after foreign patterns, or even borrow them direct, than to create one's own neologisms. Such a process is, of course, by no means unique to Byelorussian but that language does provide substantial evidence of it. In general, Russian has provided the model for Byelorussian calques in the Soviet period; calques direct from non-Slavonic languages have by and large not established themselves as literary norms and straight loan-words have taken precedence (e.g. штрэйкбрэхер over стачкалом, фейерверк over агнялёт, амонім over аднагучнік, кісларод оver тлен).

Calques from Russian in modern Byelorussian are numerous and may be divided into two types: those which correspond entirely in structure 
and those which correspond only in part (Bachankkoǔ subdivides each of these categories into those which repeat the motivation of the calqued object and those which vary it, but many of the examples he quotes under the latter heading seem too structurally remote to qualify as calques in the proper sense of the word). By far the more numerous of the two types is the former which covers the whole stylistic spectrum and includes such examples as гадзіншчык (cf. R. часовщик), цемрашал (R. мракобес), адцягнены (R. отвлеченный), абагульніць (R. обобщить). Examples of calques which correspond structurally only in part are: справаводства (cf. R. делопроизводство), ускосны (R. косвенный), відавочны (R. очевидный). Semi-calques or partial calques from Russian are also numerous; they are predominantly compound words and include such examples as лесаахоўны (cf. R. лесозащитный), славяназнаўства (R. славяноведение), дзяржплан (R. госплан).

One of the fastest-growing lexical categories of the 20th century is abbreviations, whether they be initial, syllabic or a mixture of the two. The vast increase in modern times in the number of institutions, organizations, societies and pressure groups of one kind or another has produced a situation in which, especially in the press and in specialist usage, abbreviations are a significant feature of the linguistic landscape in all the major European languages. Once again Russian frequently provides the model for Byelorussian, but this is hardly surprising since a considerable proportion of the abbreviations have to do with facets of Soviet life; some are borrowed direct (e.g. самба cf. R. самбо = самооборона без оружия), others are calques from Russian models (e.g. заг = загадчык cf. R. зав = заведующий, нам $=$ намеснік cf. R. зам = заместитель), a few are unique to Byelorussian (е.g. Інбелкульт = Інстытут беларускай культуры). The vast majority of abbreviations in Byelorussian, though derived directly from native words, have their equivalents in Russian (e.g. філфак = філалагічны факультэт; ГэС = гідраэлектрастанцыя). As far as the distribution of syllabic and initial abbreviations is concerned, the former predominated in the 1920s but since then initial abbreviations have become the more productive, though according to Bachankoŭ 'society' (whatever that may mean) is now attempting to limit their use. Even a linguist who does not believe in unnecessary interference in linguistic processes is likely to feel some sympathy with this aim in the face of such uglinesses as MAHITTMAШ or, worse still, БелНДІгіпрасельбуд!

The Soviet period has seen a particularly marked increase in foreign lexis in Byelorussian and Bachańkoú devotes almost half his book to this topic. It would be a mistake, however, to see this as a purely Soviet phenomenon, since it is one which distinguishes many other languages - the pace of technological change and the ease of international communication in the 20th century have been to a large extent responsible. Byelorussian, however, has been particularly vulnerable to penetration by foreign lexis because at the beginning of this period the modern literary language was still in a relatively underdeveloped state. In 
highly developed languages with a long and continuous literary tradition the process of assimilating foreign lexis is more sparing and moves more slowly than in 'young' literary languages which are only just beginning to develop their full range of functional styles and maximize their native resources. What the establishment of Soviet rule in Byelorussia did determine, however, was a change in the sources of foreign lexis in Byelorussian. Whereas prior to the Revolution Polish had been the major source and intermediary (it was through Polish that Latin and West European borrowings had found their way into Byelorussian over the centuries), after the Revolution, and especially after the 1920s, changes in Byelorussia's political, economic and cultural relations with other nations meant that this role was assumed by Russian. Furthermore, it was subsequently reinforced, for good or ill, by the growth of Russian-Byelorussian bilingualism. One of the dangers of bilingualism involving two languages as closely related as Russian and Byelorussian is that it is often imperfect; insufficiently clear distinction between the two may therefore lead to the adoption of loan-words in Byelorussian in their Russian rather than Byelorussian form. A good illustration of this problem is the assimilation of foreign verbs by means of the suffix -ova-, and it is interesting to note that Bachańkoù devotes a considerable amount of space (pp.146-60) to this one area in his book.

In adopting foreign verbs Russian uses, in addition to the basic suffix -ова- (-ева-), а number of variants: -изова-, -ирова-, -изирова-. Вуеlorussian and Ukrainian similarly have variants but, characteristically, not those with the element -ir-; thus for Byelorussian the standard suffixal variants are -ава- (-ява-) and -ізава- (cf. R. агитировать, активизировать but $\mathrm{BR}$ агітаваць, актывізаваць). What this reflects is the continuation of a tradition stretching back into history: in the 16th-18th centuries it was the means of adopting foreign, chiefly West European, verbs via Polish. The same was true for the earliest borrowings in Russian (е.g. атаковать, адресовать), but from the early 18th century an increase in German influence and the adoption of German loan-words without the intermediary of Polish introduced the variants -ирова-, -изирова- (from German -ieren, -isieren, themselves a means of adapting into German French verbs in -er, -iser e.g. Fr. former, Ger. formieren, R. формировать). Byelorussian, however, continued to use Polish as its medium for assimilating such verbs; indeed, this was true even after the Revolution, throughout the 1920s. It was the 1930s that saw a rash of -ipasa-forms appearing in Byelorussian for the first time, so that in Aleksandrovič's Ruska-biełaruski stoǔnik of 1937 they constituted more than $50 \%$. By the time the 1953 Russkobelorusskij slovar' appeared the proportion was down to $34 \%$, but forms with the -ir- element have continued to penetrate the language and the 1950s onwards have been a period of some confusion in which sometimes verbs appear with the -ir- element, sometimes without, sometimes in both forms. What this situation shows is the increasing influence of Russian on Byelorussian and more especially the fact, 
referred to above, that Russian is now the primary medium for the introduction of loan-words into Byelorussian. It is interesting to note, however, that this phenomenon has provoked considerable discussion and disagreement among scholars, with some favouring forms with -ir(e.g. Kamaroǔski), others forms without -ir- (e.g. Eoban).

Bachańkoŭ is in favour of tolerating both suffixes (for different verbs) and this is probably the most realistic view. However, he cannot resist sniping at those who favour forms without the -ir- element, dismissing their arguments as unfounded, denying the existence of such a tendency in Byelorussian and, in Soviet terms, tarnishing such a view with the suggestion that it represents a throwback to the 1920 s and an attempt at repelling the influence of Russian. Furthermore, he contends that some verbs which have become established in the literary language with the suffix -ава- (-ява-), е.g. акупаваць, матываваць, правакаваць, рэгуляваць, are 'cacophonous' and alien to Byelorussian! While it is gratifying to note that the Ttumačalny stounnik bietaruskaj movy does not agree with this view, the spread of forms with the -ir- element continues (e.g. the Ttumačalny stoúnik has імігрыраваць where the 1953 Russko-belorusskij slovar had іміграваць).

The spread of foreign verbs with the element -ir-is but one example of a general trend which is discernible in the development of foreign lexis in the Byelorussian literary language of the Soviet period: the increase in borrowings from and through Russian. Though this process began in the 1920s and 1930s, at that time terminological foreign borrowings often coexisted with native Byelorussian words (e.g. Згук, змык, мірлівец alongside афрыката, блакада, пацыфіст). At the same time, of course, much of the terminology associated with Soviet rule came direct from Russian, along with what Bachańkoú calls words denoting 'features of traditional Russian life'. In the 1940s and early 1950s there was less borrowing generally, though the war produced an increase in military and associated socio-political terminology, some of it distinctly exotic and ephemeral. The 1950s onwards have seen a reactivation of the borrowing process and a widening of the semantic groups of loan-words, much of it associated with the scientific and technological revolution, but also in the cultural and sporting spheres. Significantly, in the post-war period neologisms of Russian origin have tended to find their way into Byelorussian virtually unchanged, with - officially, at any rate - little of the reaction against Russian forms that characterized the early period of Soviet rule. In addition, borrowings generally are assuming an ever larger role in the language (Bachańkoǔ compares a 1927 dictionary of socio-political terminology in which loan-words constituted $52 \%$ of the entries as against $48 \%$ for native Byelorussian terms and calques with a 1970 dictionary covering the same sphere of lexis in which the corresponding proportions were $75 \%-25 \%$ ). A result of this has been the 'Byelorussianization' of foreign morphemes such as аўта-, arpa-, кіна-, тэле- etc. which are freely 
rittached to native Byelorussian roots as well as, of course, forming part of foreign loan-words.

Other developing trends in Byelorussian lexis in the Soviet period include a noticeable increase in the derivation of words with the agential suffixes -ец, -енец, -чык, -шчык, -нік, -іст, -ыст and a corresponding decline in the use of -ай, -уль, -юш, -ца; the spread, particularly outside the strictly literary language, of nouns with the suffixes -ка, -ушка, derived from a combination of adjective and noun (e.g. бязгучка $=$ бязгучная вінтоўка, чыталка $=$ чытальная зала); the substantivization of (especially feminine) adjectives (е.g. настаўніцкая, бульбяная, пажарная); the formation of compounds of the type вагон-рэстаран, кафэ-клуб, старонка-плакат еtс.

All these trends, and others, are examined by Bachańkoǔ and lead him to the conclusion that 'the riches and stylistic variety of Byelorussian's word stock testify to the fact that in the Soviet period it has been transformed into the highly developed multifunctional literary language of a socialist nation, capable of serving the needs of linguistic practice in all spheres of social activity'. (Significantly, however, a footnote exempts from this last point two areas: relations with representatives of other nations and official correspondence with central institutions and other Soviet republics where Russian fulfils the communicative function.)

So what of the future of Byelorussian and in particular its lexis? Here we return to the starting point of this article. What he regards as positive advances notwithstanding, Bachankoun is worried by the 'elemental' nature of some aspects of this development and would like it to be more 'rational' and 'purposeful'. To this end he proposes the creation of a linguistic commission attached to the Institute of Linguistics of the Academy of Sciences of the BSSR, with wide powers of 'control' over linguistic processes. Such a commission would undertake: the systematic registration and interpretation of new words and meanings not recorded in existing lexicographical works; the periodic publication of such materials with an objective evaluation of their worth and recommendations on their use; propaganda aimed at heightening kultura movy; a consultancy service for organizations and individuals on linguistic matters; and an analysis of the language of books, newspapers, journals, radio and television from a normative point of view. Should Bachańkoǔ's call be heeded and such a commission be set up, we shall look forward to reviewing its work and the future development of Byelorussian. 